ABSTRACT

Finnish Theatre Photography and the Influence of Technology This article is mainly based on interviews with three Finnish photographers', Kari Hakli, Jalo Porkkala, and Petri Nuutinen's as well as on the theatre photographs they have taken. The criterion for selecting these three photographers has been that their work spans a number of decades; therefore, the development of Finnish theatre photography can be studied from this perspective. The theatre photograph is a photo of the stage image, which is often based on the dramaturgy of the play script. The subjects and points of view of the photographer are not generally agreed on in advance with the director or the actors, but they are based on the photographer's own estimations and views. He/she interprets and transmits the performance to the audience with his images, and works in between the theatre and the spectator, but he is not the artistic producer when photographing, the performance is, i.e. he/she has not chosen lights, costumes or set design.

Technology has had a significant influence on the theatrical image and photographic equipment. With the development of materials and equipment, the

making of theatre photographs has shifted from a static process into a more

dynamic one. Finnish theatre photography has reacted quickly to aesthetic trends in both theatre and photography. In the past it was possible to photograph only static or slow-moving objects in a set situation or in a pose. Today, the photographer can move among the actors, photograph fast-moving objects with a handheld camera using the stage lighting without the need for additiona lights. The images look more as if they have been taken by an insider, someone who belongs to the team, rather than by an intruder. Theatre photographs are nowadays needed in the same way they have always been needed, as document

BIOGRAPHY

Susanna Virkki has been working as teacher and tutor at the Open University of Turku, Summer University at West-Finland and Pori Art School since 2003 , where she has taught art history, aesthetics and art philosophy. She obtained her MA in Art History at the University of Turku in 2008, concentrating on theatre, photography, semiotics and visual culture. The title of her thesis is Image, Word and Space in Theatre. Theatre Photographs of the Performance Celebration and their Semeiotics Interpretation. She began her PhD studies at the University of Turku in 2013. The title of her PhD thesis is Illusion is Exposing. Theatre Photographs as Representations of the Performance. Together with photographer Jalo Porkkala, Virkki has published an exhibition programme Light - Space - Time. Theatre photographs of 30 years for Poriginal gallery (Jalo Porkkala, Susanna Haltsonen: www.blurb.com, 2009) susanna.virkki@utu.fi

\title{
Finnish Theatre Photography and the Influence of Technology
}

\author{
SUSANNA VIRKKI
}

Theatre performance is a complex art form. The performance, which is presented in the same premises, is the same every time and yet it is always unique. It happens here and now. It is a unique work of art at the time of the performance, but it will never be complete because the atmosphere of the performance changes and interacts with its makers and the audience, i.e. presence and point of view of spectator(s) is of the utmost importance.

In this article, I investigate theatre photography and I have tried to answer the following questions how does one photograph a theatrical performance, how has technology changed photography and how has the function of theatre photography changed. The article is mainly based on interviews with three Finnish photographers - Kari Hakli, Jalo Porkkala, and Petri Nuutinen - as well as analyses of their theatre photographs. These photographers have all made significant careers in theatre photography. The criterion for selecting these three has been that their work spans a number of decades; therefore, the development of Finnish theatre photography can be studied from this perspective. Photos of theatrical performances can be said to have moved from their active use and into a different context. That is to say, the photos have been transferred to the archives as documents and fragments of the past and have become an essential part of the evidentiary record. To the researcher of theatre photographs the work will be challenging due to the vast scale and fragmented nature of the source material. A considerable number of theatre photographs are available, but most of them have not been properly archived, and pre- vious studies on theatre photographs are virtually non-existent. ${ }^{1}$

This article starts with some theoretical reflections on theatre photography and after that a short history of Finnish theatre photography is presented to provide a context for the following discussion. Finally, the work of the three Finnish photographers is analysed based on the theoretical and historical context.

\section{THEATRE PHOTOGRAPHY}

Theatre historian Barbara Hodgdon writes the following about the theatrical image: "The theatrical still is the visible remains of what is no longer visible, a fragment that steals your theater, stills of it and dis-stills from it. Considered as performance in pieces, the theater photograph undertakes a visual conversation with performance: the silent, impoverishes, partial, it seizes appearances, violently severs them from original context; inseparable from and traversed by the lived experience of the theater, it requires narrative, anecdote, to supplement it."

The theatre photograph is a photo of the stage image, which is often based on the dramaturgy of the play script. They are usually taken at the dress rehearsal, where stage circumstances are similar to the actual performance, and there are usually spectators in the auditorium. The photographer moves around on the stage and in the wings, observing. The subjects and points of view of the photograph are not generally agreed on in advance with the director or the actors, but are based on the photog- 
rapher's own estimations and views. S/he interprets and transmits the performance to the audience with his images, and works in between the theatre and the spectator, but is not the artistic producer when photographing, the performance is, i.e. s/he has not chosen the lighting, costumes or set design. Theatre photography can be viewed and used, among other things, as documentation of the staging and the theater director's tool, portrait of the actor, as an independent work of art, advertisement, or the photographer's own comment.

Theatre photography is like a stage, where the photographer, the production and its components, the viewer and, finally, the user of the photograph, meet. It is also a stage where the signs and meanings are in an ongoing dialogue. The theatre photographer thus works in-between the theater and the spectator. With his camera and photographs, he incorporates, exposes and snatches representations of moments according to his own intentions. He captures and seizes the movement of the performance in space and time. A theatre photograph is a representation of another event, the performance, and thus it is subordinate to its logic. There are actors and actresses who are present, but they are absent in their illusory roles. To the actors themselves, the moment of the performance is the reality in which they exist. ${ }^{3}$ The theatre photographer is also one of the creators of the reality of the performance. Theatre photos are like double images: they are a representation of the situation, but also images of absence and presence at the same time. Directo Annette Arlander has stated that this 'double view' is an integral part of the theater audience: the spectator sees the illusion created by the performance as well as its conditionality. In spite of this, the spectator agrees to play along. ${ }^{4}$ The theme of the double is also associated with studying theatre photographs. According to Thomas Postlewait, a photograph of the performance is complex just because of its double character, which incorporates the points of view of the performance photographer and the viewer of the images. 5

The researcher, on the other hand, looks at the images from a retrospective perspective of a past performance. Philosopher Paul Ricoeur has said that detecting absence, a lack of something, fills the void with meaning in which case the lack of significance would be the place of significance. ${ }^{6} \mathrm{~A}$ past performance is absent, so researchers do not have direct access to it. To bridge this gap, documents are needed in order to be able to reconstruct and identify the performance. So, do the viewers and interpreters of theatre photographs automatically have prerequisites for identifying and understanding the images? The starting point, the first prerequisite, of all interpretation is that the interpreter must have the ability to see something as something, seeing as.?

The second prerequisite in the process is that the interpreter must be able to experience something as something previously encountered. William Jame used the term 'the sense of sameness' to describe thi kind of identifying. ${ }^{8}$ When studying theatre photographs researchers face an abundance of possible interpretations. While looking at the images, the researcher him/herself is a part of the historical process of interpretation. This is a challenge, because the object of interpretation is the theatre photograph, which is born as a result and on the basis of another person's, the theatre photographer's, previous experiences.

The starting point of hermeneutics is the Heideggerian view that all understanding is based on the interpreter's "fore-structures of understanding". ${ }^{9}$ As the interpretation develops this pre-understanding changes and affects new interpretations, which in turn shape new forms of understanding and so on. It is only possible to understand the interpreted phenomenon in relation to the dialogue between its individual elements and the whole. ${ }^{10}$ The better the context is understood, the better the importance of its components is understood and vice versa. Inter pretation can be considered as a process in which meaning is not situated in a sign system, but in the consciousness of the person using the signs. The meanings are generated in social situations where the meaning of a particular sign may change. The meaning of the signs that are being interpreted is defined by the practices of a community and how those practices are understood. In other words, the 'truth' is an interpretation of reality and, therefore, situation-bound as well as tradition-bound. According to this logic, a realistic photograph is culture-bound convention. The researcher should acknowledge that as documents, theatre photographs express their possible meanings in cultura and symbolic codes. These codes include gestures, bodies, clothing, space and the conventions shown in the images. All these combined affect the meaning of what, how and why. History is a part of the researcher's process, but the researcher's understanding is tied to the present day. In order to guarantee the reliability and objectivity of the interpretation, the meaning must be returned to the dialogic interaction between the interpreter and the photographer. ${ }^{11}$ The meaning can also be returned to the cultural context in which interpretation takes place. In the study of theatre photography, this could mean that a criterion for the interpretations is to be sought either in the interpreter or in the dialogue between the interpreter and the object that is being interpreted. In cases where the object of interpretation cannot be clearly explicated (e.g. theatre photographs, which cannot be identified or linked to a particular production), the researcher can turn to theatre photographers and interviews with them as well as any other kind of action or method where the object of interpretation and its meanings are defined.

\section{A SHORT HISTORY OF FINNISH THEATRE} PHOTOGRAPHY AND TECHNOLOGY

Finnish theatre photography began from dance photography, which interestingly merged various core areas of the culture of photography. The history of dance photography began in the 1860s in Helsinki where Finland's oldest so far identified dance photographs were taken. ${ }^{12}$ Stage documentation and theatre photography have continued since the early decades of the twentieth century.

In the early 1900s, agrarian Finland was still fa from the urbanized and industrialized economies of some European countries. Despite this, links with the rest of Europe were frequent. Cultural influences spread largely with the help of films and magazines, and photography played an important role here. In the period of growing prosperity after the Second World War, Finnish photographers could, little by little, specialize in different photographic fields (for example advertising, theatre, dance or reportage photography).${ }^{13}$ Since the early 1920 s, however, some photographers, to some extent, had already torted to orientate themselves towards the artistic expression of their work. This was mainly seen both in advertisements for photo studios and, in the case of theatre photography, in the photographs of different theatres and individual performances. ${ }^{14}$ In Finnish theatre journals, photographs with the name of the photographer were used to introduce the upcoming repertoire of the main theatres in Helsinki. In these magazines the photos were almos always connected to the photographer. Contrary to that, in newspapers the publicity photos of plays were often left without a reference to the photographer. ${ }^{15} \mathrm{~A}$ few well-known theatre photographers noted the inferior status of theatre photographers in the production process of the performances. ${ }^{16}$ In the 1930s, the photo studios and the photographers hoped to take pictures of artists in character as well as in private, because this would make it possible to increase the efficiency of the PR-work, as well as the value and artistic significance of the photograph and thus enhance the standing of the profession. ${ }^{17}$

In theatre photography, technology has had a significant influence on the theatrical images and photographic equipment. With the development of materials and equipment, the making of theatre photographs has shifted from a static process into a more dynamic one. Finnish theatre photography has reacted quickly to aesthetic trends in both theatre and photography. Photographer Jalo Porkkala recalls in an interview that in the 1920s and 1930 s it was possible to photograph only static or slow-moving objects in a set situation or in a pose. ${ }^{18}$ Plenty of light was needed because of the slownes (low light-sensitivity) of the photographic material. The ordinary illumination of the stage was usually not enough for taking a photograph. Extra lights and sometimes the rearrangement of lights were needed in order to take a single photograph. Due to this, there is a marked difference between the theatre photographs of the past and of the present day. Older images seem staged, artificial and overacted. (Fig. 1)

Today, the photographer can move among the actors, photograph fast-moving objects with handheld camera using the pre-designed stage lights without the need of additional lights. The outcome 
looks spontaneous and reportage-like. The images look more as if they were taken by an insider, someone who belongs to the team, rather than by an intruder. ${ }^{19}$ In the late 1960 s, the black and white photo had its charm in simplifying its object. Colour, however, was desired and photographers started using it as soon as possible in the 1970s.

When using black/white film it was necessary to focus on light, shape and surfaces, whereas colour film allowed for images as colourful as the performance. Jalo Porkkala mentions as an example Pori Theatre's music play The Steamie (2002), which would appear stolid and documentary in black/ white, while colour brought sparkle and zest, which in this case was intended both in the play and in the images. The mood of the play was light and cinematic, which emphasized as well the lighting as scenery. This atmosphere was hoped to be conveyed to the viewer in the theatre photographs. (Fig. 2)

In the 1970s and 1980s, however, when black/ white as well as colour photos were taken of the same performance, the available colour technology did not meet the expectations of the photographers.

During the 1980s, photographers moved on to the so-called hybrid technology: the photographs

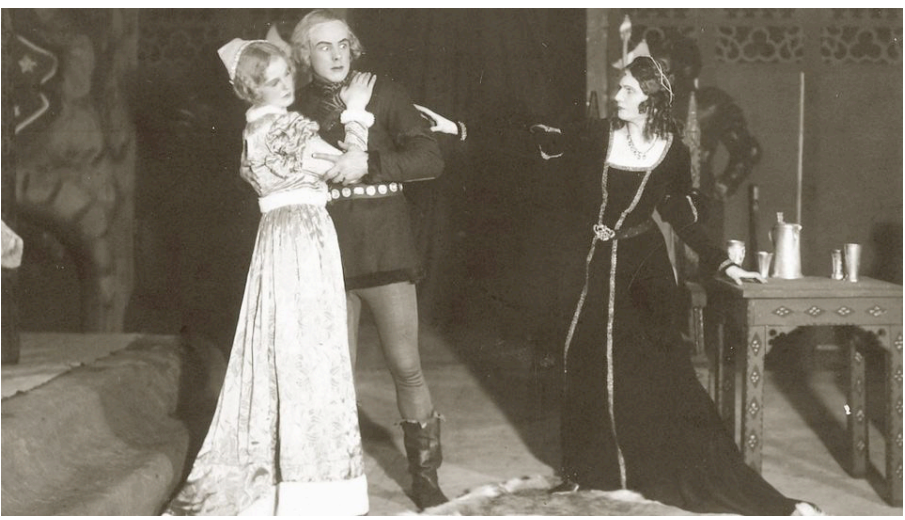

Fig. 1. Elina's Death (Elinan surma, 1931), Pori Theatre, on stage Emma Väänänen, Thure Bahne and Salli Friberg. Photo: Satakunta Museum.

were captured on film and scanned, so the prints were digital. ${ }^{20}$ Theatre photos were taken mainly for marketing purposes, but in spite of that, the photos were not manipulated. Until the 1990s, photographers preferred slides to colour negatives, for example in printing originals. Slide film had an advantage over colour negative film because these were expensive to develop and print into images, and colour reproduction did not match the level of slide film. For a long time, developing slides was cheaper than developing colour paper images and this is why the slide was the predominant method of theatre photography. ${ }^{21}$ Creating theatre photography in the $21 \mathrm{st}$-century is a goal-oriented design and construction process of a complete work of art. (Fig. 3) Photos are not only authentic records of the plays, but also transmissions of impressions. Theatre photographs exist to communicate and tell stories. Photographs are a means to widen the viewer's horizons, but it is recognized that photos are also marketing tools.

At the beginning of the new millennium, the photographers' work became completely digital. Paster than anyone could have predicted. Digital photography has changed pho-

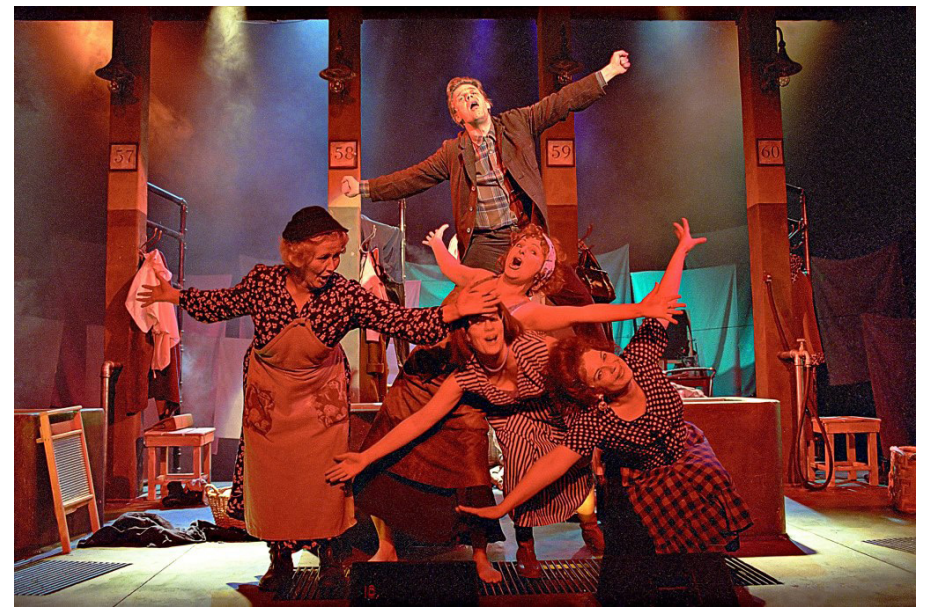

Fig.2.The Steamie (Pesulan likat, 2002), Pori Theatre, directed by Anita Myllymäki.Photo: Jalo Porkkala.

tography dramatically. The nature of a photograph a passion for it. He has photographed the Finnish reactions to mathematical data and electrical pix- many years, developing a personal way of producels. Digital photographs can be displayed, printed, ing dance imagery based on realism. With a comstored, manipulated, transmitted, and archived mission from the Helsinki City Museum, he also using digital and computer techniques without photographed Helsinki in the 1960s and 1970s, chemical processing. Digital photography has made especially buildings that were set to be demolished it possible to produce images which have no direct as well as the maritime fortress Suomenlinna becontact with reality. This in turn raises the valid fore its repair work in the $1980 \mathrm{~s}^{22}$ Hakli received question of the possibility of manipulation and the the State Prize for Photography in 1972 and some authenticity of the image in portraying the world. of his works are in the collections of The Finnish Museum of Photography in Helsinki. He has also Museum of Photography in Helsinki. He has also
taught architecture and theatre photography at the taught architecture and theatre photography at the

\section{PHOTOGRAPHER KARI HAKLI}

Kari Hakli (born in 1940) has photographed theatre performances since the $1960 \mathrm{~s}$. He has made his 40 year photographer's career in major Finnish theatre houses: the Finnish National Theatre, Helsinki City Theatre and the Finnish National Opera. After studying aesthetics, art history and archeology at the University of Helsinki, Hakli began his career as a freelance press photographer, but did not feel
Kari Hakli's theatre photos taken of the opera Boris Godunov were presented at an exhibition series in the former East Germany (the German Democratic Republic). ${ }^{24}$ In 1972, Hakli also participated in an international theatre photography event, Triennale Internationale Novi Sad in the former Yugoslavia, where he won a silver medal with black/white photos he had taken of Samuel Beckett's play Endgame 


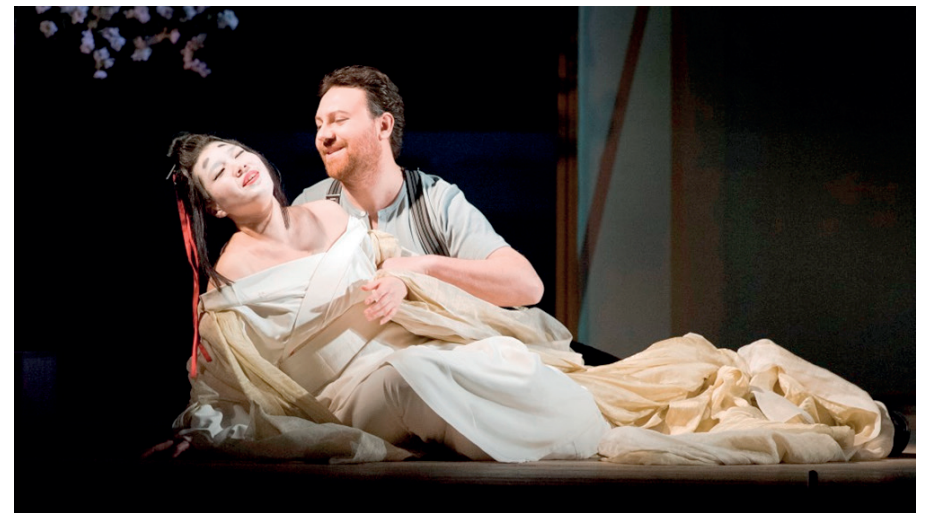

Fig. 3. Madama Butterfly (2013), Tampere Opera, directed by Katariina Lahti, on stage Kareh Son as Madama Butterfly, Alessandro Liberatore as Pinkerton. Photo: Petri Nuutinen.

(1970) ${ }^{25}$ (Fig. 4) Hall's inage buve also been fea- become cheaper in Finland after the 1960 seconomtured at the Theatre Museum in Helsinki 2005.

During the first years of the early 1970 s, photography was stigmatized due to the experimentation of its working methods necessary in order to overcome its many technical problems. The photographers' equipment and technic were quite clumsy, but in spite of this, photography in real situations was considered important. What concerned Hakli most was the question whether a performance should be photographed as stopped scenes, i.e. still lives or in action, without interfering with the performance. The latter was to him a clear option because "in my point of view, a set-up and stopped photography or straight photography, photographing in action, remains the crucial question when considering the status of interpretation in theatre photography," Hakli states. ${ }^{26}$ In an interview, Hakli remembered the 1970s when Finnish cultural life was dominated by a strong awareness of social issues. Photo journalism had experienced the rise of documentarism, as well as the golden age of the reported image, and theatre photography followed suit. Furthermore, the photographers' equipment had changed radically during the century and had

become cheaper in Finland after the 1960s econom-
ic recovery. Film cameras became smaller and lighter and the film materials' light-sensitivity multiplied. Hakli speaks of feeling a strong normative pressure from both actors and directors: the play could only be photographed in a right or a wrong way and the 'correct' images were generated in the actor's terms, not through the photographer's interpretation.

The play was to be photographed as the spectator saw it from their seat. Theatre photographs presented large stage views and mass scenes with less focus on the individual. (Fig. 5) Photographing scenes so that the dramaturgical peaks and the nuances of the actor's expressions can be optimally captured always requires a tremendous amount of shots. ${ }^{27}$ In spite of this, even the most perfect theatre photo or photographic situation cannot include the whole performance but it will always be a fragment of it. According to Hakli, it must remain as such, because "the performance is a rhythmic entity, limited in time". ${ }^{28}$ The image must show that it is a part of the whole and not just a random shot. That is why posed theatre photographs seem too artificial since they have no continuity. The poses are made for the image and their rhythm is broken because

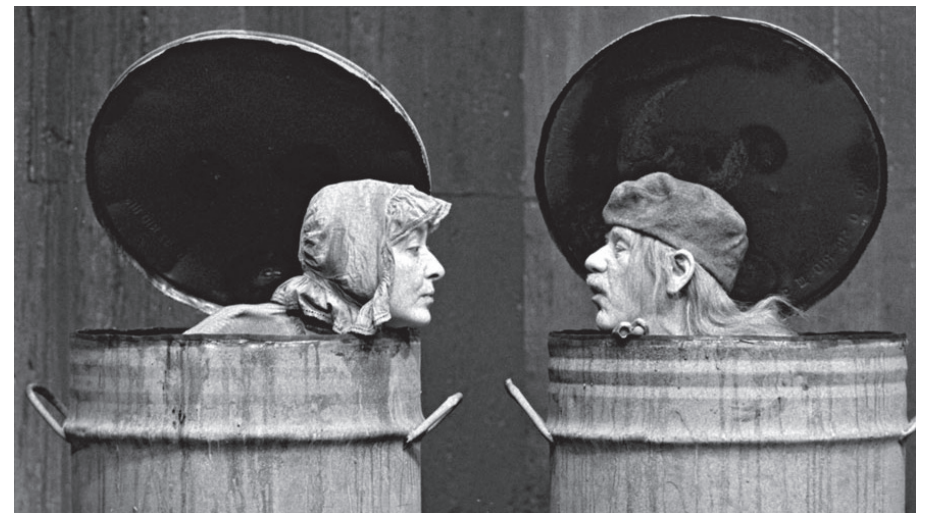

Fig. 4. Endgame (1970), Finnish National Theatre, directed by Jack Witikka, on stage Pia Hattara as Nell, Pentti Irjala as Nagg. Photo: Kari Hakli.

they have been disconnected from the whole of the performance.

In Hakli's opinion, the optimum style of theatre photography is realism, which means "a documented photographing method in which the aim is to record a performance as loyally as possible visually". The aim is a subject-oriented image which is easy to recognize. This is possible when photographing from the auditorium and using the stage lights so that the tone of the scene does not change. In Hakli's opinion, photographers try to find a connection to the dramaturgical content of the performance. "Otherwise the theatre photograph would be disconnected from the theater performance, and thus a mere shell without content," the photographer notes. $^{30}$

During his long career, Hakli has considered differences of photography and art and the essence of theatre photography. The photographer's resources are time, direction and distance. Photographic art is a matter of changing a language of expression into another language. In a theater performance, this means that Hakli, as well the other theatre photographers, has changed the language of the performance into the language of photography. Photographic el- ements are broken, analyzed and compiled into a new order. The elements of a theatre photo are the actor, set design, props and lights. Hakli has tried to arrange all of these elements into an unbroken composition, through which the artistic level or the concept of the theatre photograph can be assessed. A theatre performance can be photographically reproduced, but the 'real' theatre photos are created through the process mentioned above. In the opinion of Hakli, even though the theatre photograph is a seemingly direct document, it must meet all aspects of the image creating process. ${ }^{31} \mathrm{~A}$ photograph stops the movement and a photo should therefor the movement. (Fig. 6) Alternatively, when an actor's facial expression is in its purest form, but only visible in the blink of an eye. (Fig. 7) After all, the essence of all theatre photographs is to maintain the atmosphere of the scene. Paying attention to this discreet connection between the spectator and the performance is, together with the technical aspects, the factor that regulates the photographer's work the most.

Nordic Theatre Studies vol. 26: no. 2 be taken before the actor's body position anticipates 


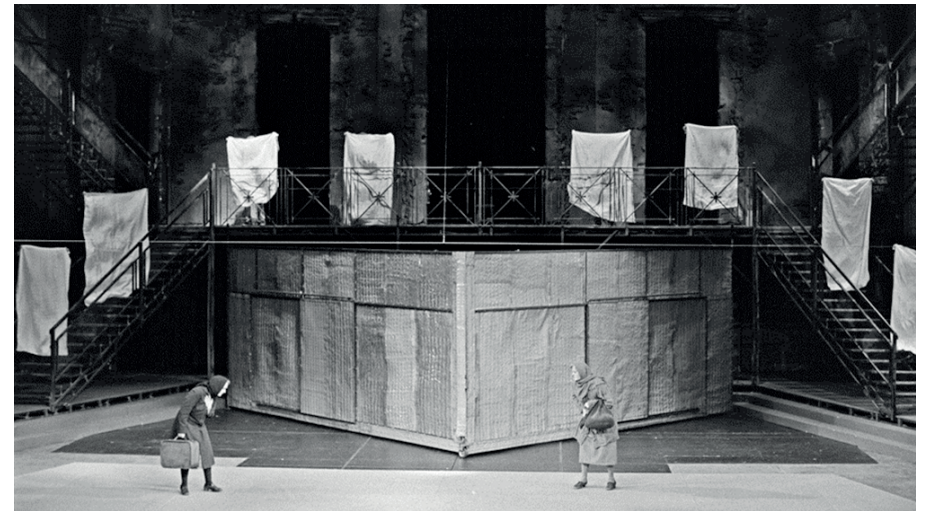

Fig. 5. Die heilige Johanna der Schlachthöfe (1972), Helsinki City Theatre, directed by Eugen Terttula. Photo: Kari Hakli.

PHOTOGRAPHER JALO PORKKALA

Jalo Porkkala (born in 1950) studied photography at

the Lahti Institute of Industrial Arts. In addition to

his 30-year career as a theatre photographer, Pork-

kala has worked, among other things, as a newspaper photographer and photography teacher as well as at the Art Institute of Kankaanpää and Satakunta University of Applied Sciences where he specializes in alternative photographic processes. ${ }^{32}$ Like Hakli, a few photographs of Porkkala are in the collections of The Finnish Museum of Photography in Helsinki. He was appointed the first theatre photographer at the Pori Theatre in $1979 .{ }^{33}$ In the fall of 2009 , when Porkkalas' career as a theatre photographer at the Pori Theatre came to an end, the team 'Porkkala \& Haltsonen' organized a theatre photography exhibition at the Poriginal gallery. They also created an exhibition programme and a type of background audio to the exhibtion. The working title of the exhibition was 30 Years of Theatre Photographs, and it featured Porkkala's photos from the plays of Pori Theatre from 1979 to $2009 .{ }^{34}$ The team sought to create a comprehensive exhibition experience in which theatre photographs, texts and the 'theatrical' background audio was intended to give the viewer the opportunity to re-experience or to recall what they had seen in a play.

When Porkkala graduated as a photographer he was fascinated by theatre photography, where he could use all the basic skills of a photographer such as processing light, space and time. In the theater, he was especially interested in challenging conditions such as rapidly changing situations, scenery and the photographic problems related to these. Interestingly, the photographer is faced with the final interpretation of the director and actors and he is, therefore, not able to change the setting of these as he would do in other circumstances. This was an important aspect for him as a photographer, basically a documentarist rather than a set designer. ${ }^{35}$ Porkkala's aim has always been to photograph in action because stopped and individually constructed situations, 'falsification', can be easily detected. The energy and rhythm of the actor's work and the continuum of the photographer's instinctive action should not be broken. ${ }^{36}$ Capturing fleeting moments brings its own difficulties, for example incorrect timing. These difficulties often accumulate in low light and in high-contrast light photography. Because of this, Porkala states, we must accept

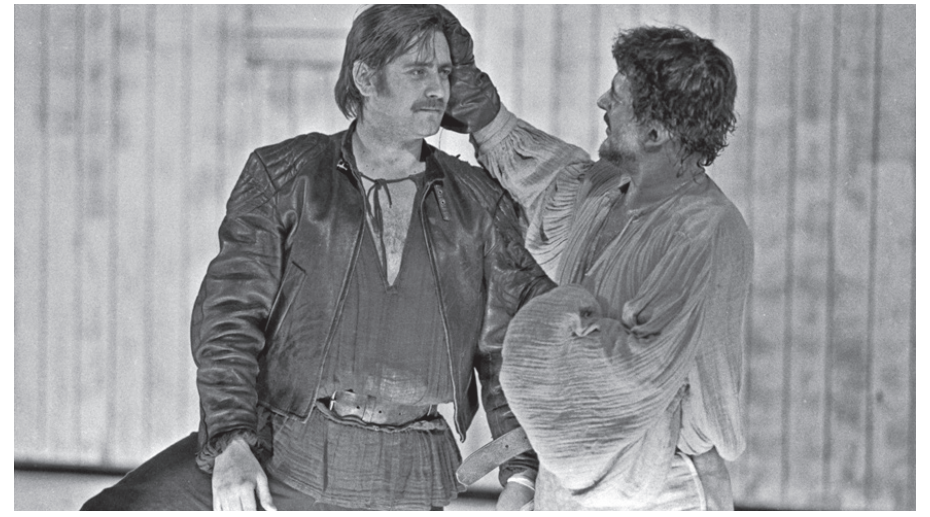

Fig. 6. Othello (1978), Helsinki City Theatre, directed by Arto af Hällström, on stage Pekka Laiho as Jago, Esko Salminen as Othello. Photo: Kari Hakli.

that there will be a lot of unsuccessful shots, but then the successful ones are 'authentic' performance images or attempts to show more or less not manipulated samples of what happens in the play". (Fig. 8) Porkkala has mentioned how, while photographing Thomas Vinterberg's Celebration (2003), he tried to pick up 'decisive moments' supporting the play's content from the movements of the actors, their expressions and gestures.

Theatre work is busy, so the only normal procedure of the theatre photographer of the past was to process the images himself. To have the photographs processed somewhere else was too time- and money-consuming and the photographer was not always able to control the quality of the images. "Often, there was not enough time to select the photos an negotiate the selection, so in many cases the solutions were the responsibility of the photographer," Porkkala recalls. ${ }^{37}$

Now, with modern technology, the photographer can send all the shots to the director half an hour after the rehearsal and the final choice of images can be agreed upon via the Internet. It is much easier to share responsibility between the members of the team, but in this case there will be more com-

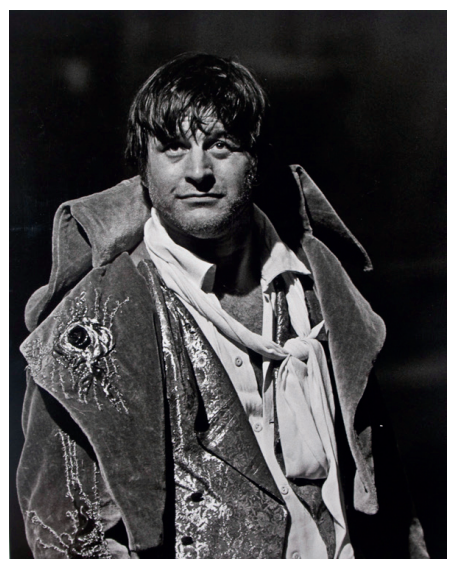

Fig. 7. Danton's Tod (1977), Turku City Theatre, directed by Ralf Långbacka, on stage Esko Salminen as Danton. Photo: Kari Hakli. 


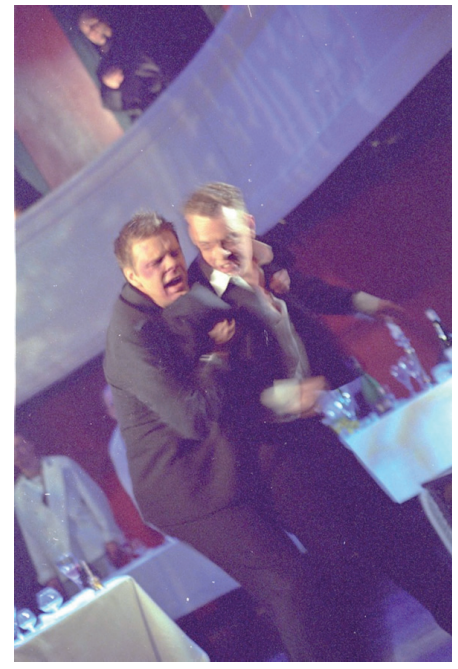

Fig. 8. Celebration (2003), Pori Theatre, directed by Olli-Matti Oinonen, on stage Vesa Haltsonen as Christian, Marko Honkanen as Michael. Photo: Jalo Porkkala.

promises. In Porkkala's, as well as the other interviewees', opinion, this has led to the fact that the photographer's personal vision may no longer be seen in the final result the way the photographer himself had thought. ${ }^{38}$ Digital technology, of course, facilitates and speeds up the work. The final result of a photography session is quickly verified. Similarly, one can easily make images for press, advertisements and newsletters by using the same original files. The images can also be processed in a variety of ways. Photographers produce the raw data, images which can be dealt with endlessly. However, despite the easiness and speed of digital photography, the difficulty of meeting deadlines has not disappeared. "Where is the saved time, which was previously used in manually developing black/white film, making contact sheets, selecting and finally doing the laborious printing job in the darkroom?" Jalo Porkkala wonders ${ }^{39}$ He thinks that digital technology has contributed to the fact that colour is used too much to highlight the commercialism, glamorous nature and impressiveness of the performance. ${ }^{40}$ But colour is a natural element in the image. Many modern photographers don't have a perception of colour use, because it comes directly from the digital camera and it can be indefinitely processed in Photoshop. "In some way, today's theater photos are no longer faithful to the photographed object in the same way they were at the time of black/white films," Porkkala ponders and continues, "black/ white film material has its own expression and will, which had to be learnt" ${ }^{41}$ Digital colour images are easy to modify and combine, producing special effects. In Porkkala's opinion, this has led to the fact that the theatre photograph is now difficult to distinguish from other images. ${ }^{42}$

\section{PHOTOGRAPHER PETRI NUUTINEN}

Petri Nuutinen (born in 1955) studied photography at the Lahti Institute of Industrial Arts, graduating in 1977. He is a freelance and fine art photographer who has photographed theatre productions since the 1980s and continues to do so for the Tampere Opera, among others. (Fig. 9) He was finalist in the Fotofinlandia competition in 1994 and some of his works are in the Finnish State Art Collection. In addition to his work as a freelance photographer, he has worked as a photojournalist, a press photographer e.g. for Soundi Magazine, picture editor and graphic designer since 1978. He has also taught photography and worked as a lecturer of photojournalism at the University of Tampere.

Nuutinen has been an assistant to several foreign photographers during their visits to Finland. He has held group and solo exhibitions since 1977. Since 1997, he, together with fine art photographer Marj Pirilä, has created action-based works of art, which are based on the principle of the camera obscura. While considering his own theatre photographing method, Nuutinen notes that he prefers reportage-like close-up photography, where he tries to get close to the actors, 'in their skin'. This method requires more presence in rehearsals, but also serious reflection on the theme of posing. He asks the actors for permission to take close-up photos and, according to feedback received, Nuutinen's way of photographing has led them to live better in the moment while acting because at the photographic moment, the intensity of the scene is directed freely to the camera. Photographing actors' close-up in front of the camera reveals facial expressions and emotions that the theater audience may not see during the theatrical performance due to the distance between the actor and the spectator. Nuutinen has received excellent feedback from actors on these intensive photo sessions because the photographer is familiar and reliable as well as a part of the team, the actors have felt more relaxed, "doing theater in earnest" Like Hakli and Porkkala, Nuutinen also thinks that theatre photography should take place during live productions, seizing the moment. Even if the lights on the set may be challenging, the photographer should make the most out of the prevailing conditions. ${ }^{44}$ The performance is not changed or improved because it is the theatrical photographer who adjusts his work to the performance. The photos are

documents, not independent images. They reflect the performance and its spirit and "good theater photographs will reconstruct the performance". ${ }^{45}$ Today, in Nuutinen's opinion, the situation is different. The photographs are taken of unfinished performances only because the schedules in theatre are tight and the marketing material is needed early. Due to this, in the future, one will not be able to go back to the performance by using these images.

According to Nuutinen, theatre photographs are in a category apart from photographic art. ${ }^{46}$ Theatre images highlight documentarism since taking theatre photographs is photographing theatrical performances. Nuutinen does not regard theatre photography as art because the theatre performances are not his own visions. Instead, the outcome is a combination of many factors. A play is a collective performance in which the photographer has a role of his own. In this regard even though the theatre photo is not considered art, it does not reduce the value of the image. On the other hand, Nuutinen admits that even a single photograph can be art or have artistic significance. For example, the pro-

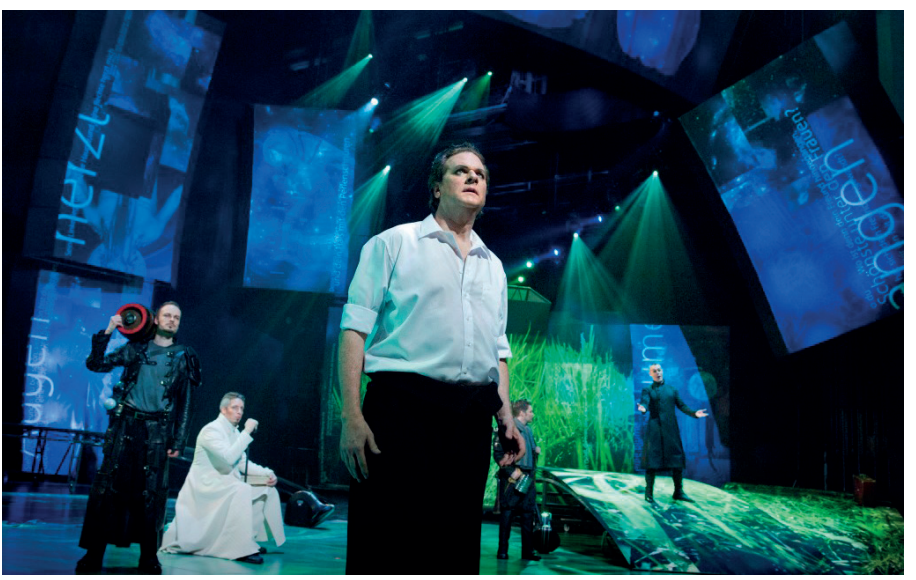

Fig. 9. Tannhäuser (2012), Tampere Opera, directed by Vilppu Kiljunen, on stage Richard Decker as Tannhäuser. Photo: Petri Nuutinen. 
gramme leaflet of the play The Black Love, which is based on the novel of Väinö Linna, was full of artistic solutions that Nuutinen could actually influence. ${ }^{47}$ (Fig. 10) So the image could be the photographer's opinion or creative interpretation about the performance. At this point I have to say that the exception proves the rule, because Nuutinen's theatre photographs have been exhibited in a gallery. In 1991 , he joined up with the other photographers to create a theatre photography exhibition called New Theatre Photography in Tampere. ${ }^{48}$

\section{CONCLUDING REMARKS}

Belief in the possibility of reconstructing the theatre performance by using the preserved documents seems to be almost lost in looking at today's theatre photographs. ${ }^{49}$ In the opinion of Reino Bragge, director of Tampere Theatre, theatre photographs are nowadays needed, "in the same way they have always been needed, as documents of the performance".$^{50}$ Currently, performances are captured in motion with either one or sometimes even more than one

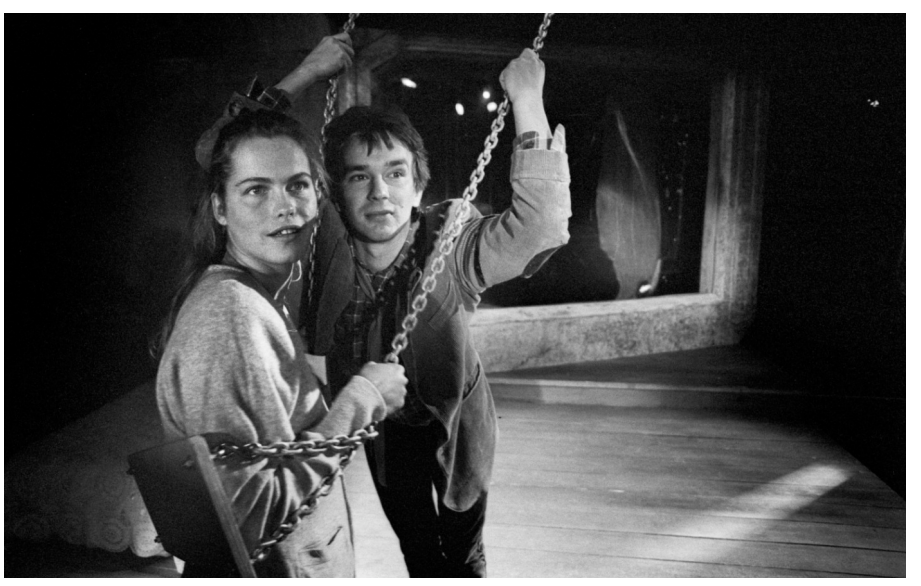

Fig. 10. The Black Love (1988), The TTT-Theatre, directed by Juhani Niemelä, on stage Katja Kiuru as Marjatta Salmela, Matti Rasila as Pauli Haantie. Photo: Petri Nuutinen. stage as a whole, that is to say, its scenery or lights. The director can see the performance in a new way by looking at theatre photographs, but this requires a photographer who has the time to get involved in the performance. Today's "tight schedule" theatre photos are in Hurme's point of view, "cheap advertising aesthetics that come near to ridiculing the viewers". ${ }^{56}$ Photographer Leena Saraste's view is that anyone is able to take proper pictures with modern cameras, but then the visual and communicative level of the image is of secondary importance. "The images are cheap raw material, which is modified according to the situation and need. There is no longer a guarantee of content and quality, because theatre images have changed from documents into individual advertising images, in which case presenting the plot of the performance with the help of images becomes impossible." 57

The photograph has a liminal status; and that is especially true of the theatrical photograph in which the usual rules and practices of photography are denied. The performance disappears from time and space, but theatre photos are evidence of what has happened on stage. They are visible remains of what is no longer present. Despite the ever increasing capabilities of manipulation, photography and the technology of image capture generally offer a record, a (unstable) proof that "that something was there". The pictorial representation of theatre photography constitutes an in-between betwixt fine and commercial art. Theatre photographers do not consider the set-up or artificially constructed photo as genuine theatre photographs because they lack the photographer's own vision. The staged image is only a snapshot, in which the awareness of being photographed affects the self-control of the people who are posing. According to the photographers, such images are misleading as to the visual truth of performance; it does not have any correlation with the visuality of performance. In an authentic theatre photograph, an actor brings into the image his own personality, intensity as well as a connection to the other actors, spectators, and the whole space. The photographer must have instinctive insight into the situation of the drama. Thus, the photographer will be able to take pictures that portray the power of presence in the performance. The photographer can capture fleeting moments of the performance and the actors' work. The photographer has the power and the opportunity to recreate the performance so that it has its own story to tell. 


\section{NOTES AND REFERENCES}

1 In Finland, theatrical photographs are archived, among other places, in the Theatre Museum, The Finnish Museum of Photography, National Board of Antiquities, Kuopio Museum of Cultural History, theatres and photographers, i.e. Kari Hakli's large collection is in the Theatre Museum.

2 Barbara Hodgdon, "Photography, Theater, Mnemonics: or, Thirteen Ways of Looking at a Still" in Theorizing Practise: Redefining Theatre History, W. B. Worthen and Peter Holland, eds., Palgrave Macmillan, London 2003 p. 89. See also Rebecca Schneider, "A Small History (of) Still Passing" in Dynamics and Performativity of Imagi nation. The Image between the Visible and the Invisible. Bernd Huppauf and Christoph Wulf, eds., Routledge, New York 2009, pp. 256-7.

3 I liken actors in role to people in hypnosis. The actors consciousness in role is like 'another scene'. S/he is scene on which things are represented, but it is possible that $s /$ he does not perform to the audience?

4 Annette Arlander, Esitys tilana. Acta Scenica 2, The Theatre Academy, Helsinki 1998, pp. 23, 62.

5 Thomas Postlewait, "Historiography and the Theatrical Event: A Primer with Twelve Cruxes" in Näkökulmia menneeseen. Teatterihistorian kirjoittamisen perusteita ja käytännön sovellus: Uusi Teatteri 1940-1941, Pirkko Koski, ed., The Theatre Museum, Helsinki 1997, p. 12.

6 Ibid., p. 13.

7 Henry Bacon, "Tulkitsemisen taito: Paul Ricoeurin kaksi hermeneutiikkaa" in Mediatutkimuksen vaeltava teoria, Tuomo Mörä, Inka Salovaara-Moring, Sanna Valtonen, eds., Gaudeamus, Helsinki 2004, p. 326. This is the notion of the philosopher Marcus B. Hester. Hester depicts the two aspects of a metaphor: imagery as well as seeing as. Ricoeur has used the notion of seeing as in his book La métaphore vive, Seuil, Paris 1975.

8 Seppo Sajama, "Identiteetin ajallisuus" in Aika, Sam Pihlström, Arto Siitonen, Risto Vilkko, eds., Gaudeamus, Helsinki 2000, p. 75. In his article "Identiteetin ajallisuus", Sajama has translated the notion of the sence of sameness into Finnish as samuuden tunne.

9 Lauri Rauhala, Hermeneuttisen tieteenfilosofian analyyseja ja sovelluksia, Yliopistopaino, Helsinki 2005, p. 35. The extract has previously been published as Eksistentiaalinen fenomenologia hermeneuttisen tieteenfilosofian menetelmänä, Tampereen yliopisto, Tampere 1993. According to Rauhala, pre-understanding is not understanding in a conscious mind, but rather it refers to the conditions of actual understanding and the shaping of the content of understanding in human disposition.

10 Hanna Meretoja, "Itseymmärryksen kulttuuris-historiallinen välittyneisyys Gadamerin ja Ricoeurin hermeneutiikassa" in Kohtaamisia ajassa. Kulttuuribistoria ja tulkinnan teoria, Cultural History - Kulttuurihistoria 3, Sakari Ollitervo, Jussi Parikka, Timo Väntsi, eds., k\&h, Turku 2003, p. 58.

11 Rauhala, op. cit., p. 35. See also Hans-Georg Gadamer, Hermeneutiikka. Ymmärtäminen tieteissä ja filosofiassa Vastapaino, Tampere 2004. (Original articles included in Gesammelte Werke, Parts 2 and 4, J. C. B. Mohr, Tübingen 1986 and 1987.)

12 Valokuvan tanssi. Suomalaisen tanssin kuvat 1890-1997. Dance in Finnish Photography, Hanna-Leena Helavuori, Jukka Kukkonen, Riitta Raatikainen, Tuomo-Juhani Vuorenmaa, eds., Pohjoinen, Oulu 1997, p. 170. The first theatre photographs that were taken without additional light and shot during the performance date as far back as the 1920s (for example in Germany).

13 Ibid.

14 Ibid. At first theatre photographs and portraits of actors were taken by the leading studio photographers of the time.

15 Ibid

16 Ibid. Well-known photographers were, for instance, Jukka Kuusisto (KuvaSampo), Heinrich Iffland and A. J. Tenhovaara.

17 Ibid., pp. 171-2.

18 Jalo Porkkala, e-mail to the author, 29 January 2014

19 Ibid.

21 Wikipedia, http://fi.wikipedia.org/wiki/Diafilmi (accessed 1 February 2014)

22 Kari Hakli, Aika. Valokuvajaan Suomenlinna. En photograf ser på Sveaborg. Photographers Suomenlinna, Musta Taide - Finnfoto, Helsinki 1998.

23 In 1973, the name changed to University of Industrial Art Helsinki. The School of Art and Design, which was founded in 1871 as the Craft School, has grown into one of the most international universities in Finland. I became a part of the Aalto University in 2010 and the name merged to form Aalto University School of Arts, Design and Architecture.

24 Some of the images are in the collections of The Finnish Museum of Photography. Leena Saraste, personal com- munication, 16 January 2014.

25 Kari Hakli, interview with the author, 31 October 2012. 26 Kari Hakli, interview with the author, 24 October 2014.

27 A photographer who has set himself high standards takes many more photos than the employer expects of him. Hakli may have used 7-20 rolls of film to photograph one performance. One film roll consisted of 36 photos, so photographing one play may have resulted in 252-720 photos, all of which had to be handled by the photographer. Kari Hakli, interview with the author, 24 January 2014 .

28 Ibid. Comparing opera arias as separate self-presentations.

29 Ibid.

32 Jalo Porkkala, Köyhä dagerrotyyppi - alternative photo graphic processes, Satakunta University of Applied Scienc es, Pori 2012.

33 Jalo Porkkala, interview with the author, 1 August 2009, e-mail to the author, 29 January 2014. Porkkala's last assignment for Pori Theatre was The Canine Kalevala in 2009

34 Jalo Porkkala and Susanna Haltsonen, Valo - tila - aika. Teatterivalokuvia 30 vuodelta, programme for the photo exhibition in the Poriginal gallery, www.blurb.com, 2009

35 Jalo Porkkala, e-mail to the author, 29 January 2014.

36 Ibid.

37 Ibid.

38 Ibid; Petri Nuutinen, interview with the author, 23 January 2014; Kari Hakli, interview with the author, 24 January 2014.

39 Porkkala and Haltsonen, op. cit.

40 Jalo Porkkala, e-mail to the author, op. cit.

41 Ibid.

42 Ibid.

44 When film sensitivity increased sufficiently, the ideal of ambient light superseded illumination. This started to take place in the late 1960s. Leena Saraste, personal communication, 7 March 2014

45 Petri Nuutinen, interview 23 January 2014.

46 Saraste, Leena. Valokuva. Muisto, viesti, taide, Musta Taide, Helsinki 2010, pp. 146 and 152. According to Leena Saraste, previously top-rated photographs and amateur works were highlighted as art but now according to the prevailing institutional conception of art, art is what is made by the artist and intended for the presentation of art. The photo is the photographer's subjective interpretation of the external, a reality that has existed at least momentarily. In a way, the photographer acts between this reality and tradition.

47 Ibid

48 Petri Nuutinen, e-mail to the author, 3 March 2014

49 Kari Hakli, "Teatterivalokuvauksen nousu ja rappio" [The Rise and Fall of Theatre Photography] in Teatteri no. 7, 2011, p. 48.

50 Reino Bragge, e-mail to the author, 6 February 2014

51 Ibid.

52 Teemu Loikas, interview with the author, 12 February 2014

53 Ibid.

54 Juha Hurme, interview with the author, 9 February 2014

55 Ibid.

57 Leena Saraste, personal communication, 16 January 2014. 